\title{
Leucocyte numbers and phagocytic activity in turbot Scophthalmus maximus following immunization with Vibrio damsela and Pasteurella piscicida O-antigen bacterins
}

\author{
M. M. Santarém, A. Figueras* \\ Instituto de Investigaciones Marinas - CSIC, Departamento de Biologia y Patologia de Organismos Marinos, \\ Calle Eduardo Cabello, 6, E-36208 Vigo, Spain
}

\begin{abstract}
The effects of 2 injected bacterins, Vibrio damsela and Pasteurella piscicida $\mathrm{O}$-antigen bacterins, on the cell type composition of the peripheral blood and head kidney and on the phagocytic activity of the head kidney leucocytes were studied in turbot Scophthalmus maximus L. Blood and head kidney samples were collected from treated and non-treated turbot at different times in the $168 \mathrm{~h}$ period after injection. The number of neutrophils increased markedly in the peripheral blood of $P$. piscicida $\mathrm{O}$-antigen injected turbot $24 \mathrm{~h}$ after injection, being significantly higher $(\mathrm{p}<0.01)$ than the neutrophil number in $V$. damsela O-antigen injected turbot. Forty-eight hours after injection, the numbers of head kidney neutrophils and macrophages in $V$. damsela and in $P$. piscicida $\mathrm{O}$-antigen injected turbot increased significantly $(p<0.05)$ compared with those in saline-injected turbot while the neutrophils in the peripheral blood decreased in fish treated with each of the vaccines. Turbot neutrophils have peroxidase-positive granules and also showed phagocytic capability. The phagocytic rate of the peripheral blood and head kidney phagocytes was higher in turbot injected with bacterins than in the saline-injected turbot, with the maximum phagocytic activity occurring $48 \mathrm{~h}$ after injection. Phagocytic activity of phagocytes in peripheral blood, kidney, and spleen was equal. Our data show that the phagocytes of turbot have a low phagocytic affinity for sheep red blood cells in comparison to what has been reported for rainbow trout. Both $V$. damsela and $P$. piscicida $O$-antigen elicited a similar level of a non-specific immune response.
\end{abstract}

KEY WORDS: Turbot Non-specific immunity - Phagocytosis - Vibrio damsela - Pasteurella piscicida

\section{INTRODUCTION}

Since 1985, turbot Scophthalmus maximus L. culture has developed into an important aquaculture industry in Galicia (northwestern Spain). The development of turbot culture has resulted in an increase in disease problems involving mainly bacterial infections (Toranzo et al. 1987, Toranzo \& Barja 1990, Toranzo et al. 1990, Fouz et al. 1991, Toranzo et al. 1993). Vibriosis is one of the most serious problems in turbot and other marine fish (Toranzo \& Barja 1990). Good protection

- Addressee for correspondence.

E-mail:pato1@iim.csic.es against Vibrio anguillarum has been obtained in turbot (Baudin Laurencin \& Batellier 1986, Dec et al. 1990) and sea bass Dicentrarchus labrax L. (Dec et al. 1990) with a $V$. anguillarum bacterin. Recently, a new pathogen, Vibrio damsela, has been described as causing mortalities in some turbot farms from Galicia (Fouz et al. 1991).

Pasteurellosis caused by Pasteurella piscicida, an important bacterial disease causing high mortalities in yellowtail Seriola quinqueradiata in Japan (Kimura \& Kitao 1971, Kusuda \& Yamaoka 1972), has also recently been detected in juvenile gilthead sea bream Sparus aurata cultured in Spain (Toranzo et al. 1991). Although no mortalities were detected in turbot, viru- 
lence assays with $P$. piscicida revealed that it was pathogenic for this species (Toranzo et al. 1991). The effectiveness of vaccination in the control of pasteurellosis using different vaccine preparations administered by several routes has been reported (Fukuda \& Kusuda 1981, 1985, Kusuda \& Hamaguchi 1988)

Phagocytic functions appear to play a very important role in the protection of fish against pathogens (Ellis et al. 1976, Rijkers 1982, Finco-Kent \& Thune 1987). It is known that lipopolysaccharide (LPS) preparations, also referred to as O-antigen preparations, from fish pathogenic bacteria are effective in eliciting nonspecific defence mechanisms in fish (Anderson \& Jeney 1991, Anderson et al. 1991) and protection against Aeromonas salmonicida (Jeney \& Anderson 1993). Vibrio damsela and Pasteurella piscicida O-antigen bacterins slightly increased phagocytic activity by spleen leucocytes and the specific immune response in turbot (Santarém \& Figueras 1994). Jeney \& Anderson (1993), working with rainbow trout Oncorhynchus mykiss, showed that the injection of Yersinia ruckeri $\mathrm{O}$-antigen caused an increase in the number of neutrophils and monocytes in the peripheral blood and in the enhancement of non-specific defence mechanisms. Migration of neutrophils from the kidney to the peripheral blood in response to the bacterial stimulus has also been reported (Park \& Wakabayashi 1989).

At present, there are no data on the leucocyte response against bacterial infection in turbot. The effects of 2 bacterins, Vibrio damsela and Pasteurella piscicida O-antigen bacterins, on the phagocytic response of head kidney leucocytes and on the leucocyte composition of the blood and kidney were therefore studied in turbot. In addition, the phagocytic activity of the peripheral blood phagocytes and that of the haemopoietic tissues (kidney and spleen) against $V$. damsela $\mathrm{O}$-antigen were also compared

\section{MATERIAL AND METHODS}

Experimental animals. Turbot Scophthalmus maximus of 8 to 10 and 25 to $30 \mathrm{~g}$ were obtained from a commercial fish farm. The turbot were acclimatised to the laboratory conditions for $3 \mathrm{wk}$. They were maintained at $18^{\circ} \mathrm{C}$ and fed daily with a commercial diet.

Antigens. Vibrio damsela (strain RG 191) and Pasteurella piscicida (strain DI-21) isolated from turbot and gilthead sea bream, respectively, were kindly provided by the Microbiology Department, Universidad de Santiago de Compostela, Spain. V. damsela was plated on Tryptic Soy Agar (TSA, Difco) and P. piscicida on Brain Heart Agar (B.HA, Oxoid) both supplemented with $1.5 \% \mathrm{NaCl}$. The $V$. damsela and $P$. piscicida bacterins were made from 24 and 48 h growths respectively. The growth was harvested from 15 l of trypticase soy broth and brain heart infusion, respectively, and processed to obtain $\mathrm{O}$-antigen preparations using the alcohol-acetone process (Edwards \& Ewing 1972). In a preliminary test, the optimal stimulatory dose of the $\mathrm{O}$-antigen bacterins was determined to be $100 \mu \mathrm{g}$ fish $^{-1}$ (8 to $10 \mathrm{~g}$ ) using the phagocytosis assay with head kidney leucocytes.

Experimental design. Fish weighing 8 to $10 \mathrm{~g}$ were inoculated by intraperitoneal injection (i.p.) with $100 \mu \mathrm{gg}$ of Vibrio damsela or Pasteurella piscicida Oantigen suspended in $0.1 \mathrm{ml}$ of sterile phosphate buffered saline (PBS). The controls were injected with $0.1 \mathrm{ml}$ of PBS. At sampling times immediately before and at $6,12,24,48,72$, and $128 \mathrm{~h}$ after injection, the fish were anaesthetized in MS-222 (Argent Chemical, USA) and blood samples were taken by caudal puncture. Whole blood was used for the determination of leucocyte numbers and differential counts. The plasma, obtained after centrifugation, was used to determine the plasma protein content. After bleeding, the head kidney of each fish was excised and a cell suspension was prepared for the determination of differential cell counts and phagocytic activity.

For the comparative study of the phagocytic activity of the kidney, spleen, and blood leucocytes, turbot of 20 to $30 \mathrm{~g}$ were injected i.p. with $100 \mu \mathrm{g}$ of Vibrio damsela O-antigen or with PBS (the controls). The phagocytic activity was evaluated $48 \mathrm{~h}$ after injection.

Determination of haematocrit, leucocyte numbers, and differential cell counts in the peripheral blood. At each sampling time, 5 fish of each group were bled. Haematocrit values (the percentage of the total blood volume occupied by red blood cells) were determined after centrifugation for $10 \mathrm{~min}$ at $2000 \times \mathrm{g}$. The total number of circulating leucocytes was calculated from haemocytometer counts. Blood smears were fixed in $100 \%$ methanol and stained with May-Grunwald Giemsa. Mature lymphocytes, neutrophils, monocytes, and thrombocytes were identified using standard morphological criteria given by Burrows \& Fletcher (1987). Only the thrombocytes with a distinct oval shape were counted as such. A total of 100 leucocytes were counted in each smear to obtain the percentage of the different types of leucocytes present.

Determination of differential cell counts in the kidney. At each sampling time, 5 experimental fish and 5 control fish were killed and the head kidney removed. Each organ was placed in $5 \mathrm{ml}$ of ice-cold EMEM (Eagle Minimum Essential Medium) containing 10 units $\mathrm{ml}^{-1}$ of heparin, 50 units $\mathrm{ml}^{-1}$ of penicillin, and $50 \mathrm{\mu g}$ $\mathrm{ml}^{-1}$ of streptomycin, and supplemented with $10 \%$ of new-born calf serum (EMEM10). Cell. suspensions were prepared by teasing the tissues with forceps in a Petri dish. After sedimentation of tissue debris in 
ice-cold EMEM for $10 \mathrm{~min}$, the supernatants were removed and washed twice in the above medium at $300 \times g$ for $10 \mathrm{~min}$ at $4^{\circ} \mathrm{C}$. After resuspending the cells in $2 \mathrm{ml}$ of the above medium, the total number of cells per kidney was calculated by counting the cells at a dilution of 1:100 in a haemocytometer chamber. Cell viability was determined by trypan blue exclusion. Smears of cell suspensions were prepared as has already been described for circulating leucocytes. Mature leucocytes, including neutrophils, macrophages, lymphocytes, and thrombocytes were identified. Differential counting of 100 leucocytes per slide for each fish was conducted.

Isolation of phagocytes from blood, head kidney, and spleen for phagocytic assays. Cell suspensions from head kidney and spleen were obtained as described above. Two ml of the cell suspension and the heparinized blood diluted $1 / 2$ in PBS were layered over discontinuous Percoll density gradient composed of $2 \mathrm{ml}$ of $60 \%$ and $2 \mathrm{ml}$ of $35 \%$ Percoll (Pharmacia). After centrifugation at $400 \times g$ for $30 \mathrm{~min}$, the cells at the 35 to $60 \%$ interface were harvested, washed 3 times, and suspended in above medium at a concentration of $1 \times 10^{7}$ leucocytes $\mathrm{ml}^{-1}$. Cell viability was determined by trypan blue exclusion

Phagocytosis assay. Phagocytosis assays were performed according to Anderson \& Jeney (1991). Sheep red blood cells (SRBC) were fixed with $3 \%$ glutaraldehyde in PBS for $17 \mathrm{~h}$, washed 5 times in PBS, and resuspended to a final concentration of $10 \%(\mathrm{v} / \mathrm{v})$ in PBS. Samples $(100 \mu \mathrm{l})$ of the cell suspension were placed in microtitre wells and incubated with $1 \mu$ l of $10 \%$ SRBC suspension for $30 \mathrm{~min}$ on a shaker at $18^{\circ} \mathrm{C}$. Phagocytosis was stopped by placing the samples in an ice bath. Following this, the preparations were briefly centrifuged $\left(4^{\circ} \mathrm{C}\right.$ at $\left.150 \times g\right)$. Two-thirds of the supernatant were removed, and the pellet was resuspended and smeared onto a glass slide. After drying, the smears were fixed in ethanol:formaldehyde (90:10) and stained for peroxidase activity using 3-3'-dimethylbenzidin (Quaglino \& Flemans 1958) and Giemsa. The percentage of cells with phagocytized SRBC was determined by examining 100 phagocytic cells in each smear under the microscope.

Protein determination. Protein concentration in blood plasma was estimated using the BioRad protein assay (BioRad, Richmond, CA, USA) with bovine serum albumin as standard (Sigma). Optical density at $595 \mathrm{~nm}$ was measured in a Hewlett Packard 8452A spectrophotometer

Statistical analysis. The mean and the standard deviation (SD) for the various treatment parameters were calculated. Means were compared using Student's $t$-test. Differences were considered statistically significant at $p<0.05$.

\section{RESULTS}

No significant differences in the haematocrit values were observed between immunized and control fish at any of the sampling times (Fig. 1).

As shown in Fig. 2, the total number of circulating leucocytes increased post-injection, reaching a maximum between 24 and $48 \mathrm{~h}$ post-injection with Vibrio damsela O-antigen and at $24 \mathrm{~h}$ in Pasteurella piscicida O-antigen injected fish. Significant differences between the number of circulating leucocytes $(p<0.05)$ of $V$. damsela O-antigen and P. piscicida O-antigen injected fish were found $48 \mathrm{~h}$ after injection. However, at any given sampling time, the total leucocyte count

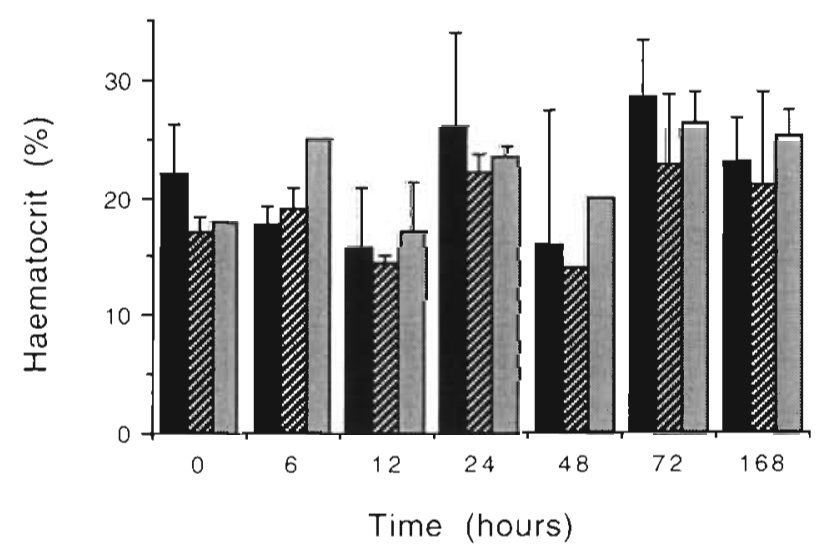

Fig. 1. Scophthalmus maximus. Haematocrit values at various times after injection of turbot with Vibrio damsela $\mathrm{O}$-antigen bacterin ( $\mathbf{\square})$ Pasteurella piscicida $\mathrm{O}$-antigen bacterin $(\mathbf{Q})$, or phosphate buffered saline (PBS) (D). Values are means \pm SD

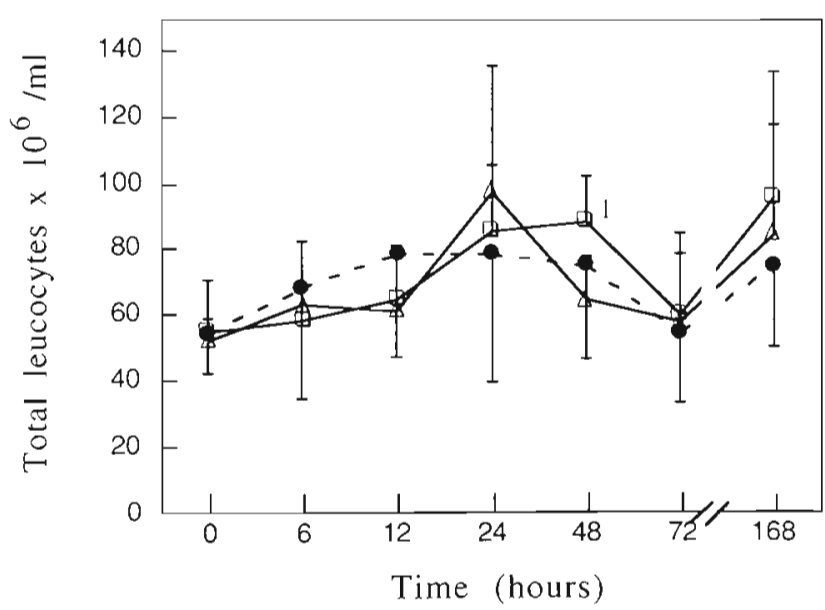

Fig. 2. Scophthalmus maximus. Total peripheral blood leucocytes in turbot at various times post injection with Vibrio damsela O-antigen ( $\square$ ), Pasteurella piscicida O-antigen $(\Delta)$, or PBS ( Each data point represents the mean \pm SD from 5 fish. 1: significant differences $(p<0.05)$ between $V$. damsela $O$-antigen and $P$. piscicida $\mathrm{O}$-antigen immunized fish 
for fish receiving either of the bacterins was not significantly different from that for the saline-injected control fish.

The proportion of neutrophils in the blood increased after injection, reaching a maximum level $24 \mathrm{~h}$ post-
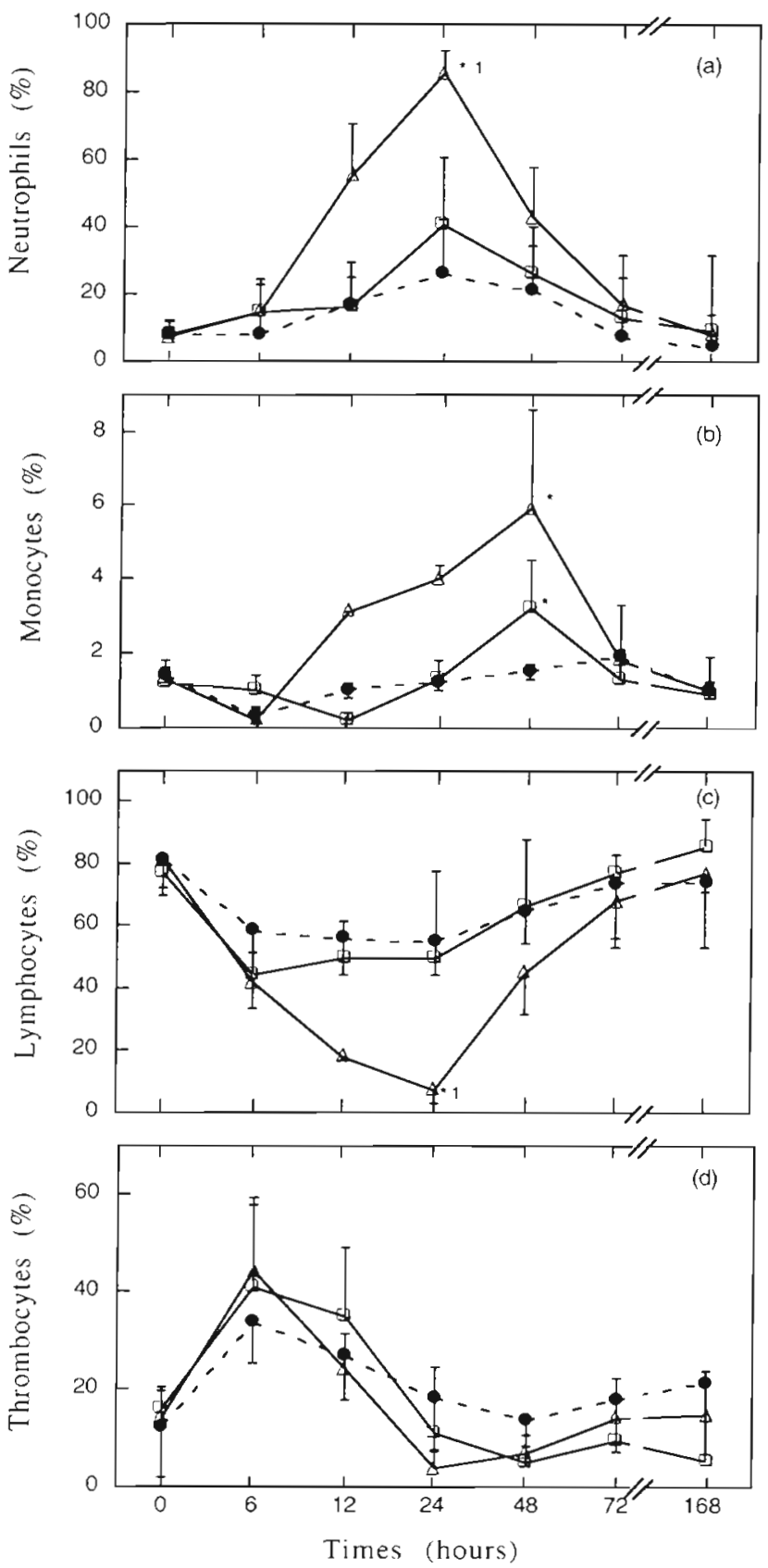

Fig. 3. Scophthalmus maximus. Differential cell counts of peripheral blood leucocytes at various times after injection of turbot with Vibrio damsela O-antigen (), Pasteurella piscicida O-antigen ( $\triangle$ ), or PBS ( ) Each data point represents the mean \pm SD from 5 fish. * Significant differences $(p<0.05)$ between groups treated with bacterins and salme-treated groups. 1. significant differences $(p<0.05)$ between $V$. damsela $\mathrm{O}$-antigen and $P$. piscicida $\mathrm{O}$-antigen injected fish injection in both the O-antigen and saline-treated fish (Fig. 3a). However, the proportion of neutrophils rose most dramatically in fish injected with Pasteurella piscicida $\mathrm{O}$-antigen bacterin so that by $24 \mathrm{~h}$ after injection the proportion of neutrophils in these fish was significantly different $(p<0.01)$ from that for the salineinjected controls. No significant differences were found $(\mathrm{p}>0.05)$ between Vibrio damsela $\mathrm{O}$-antigen treated fish and saline-treated fish. At this time (24 h), significant differences $(\mathrm{p}<0.01)$ were found between the $2 \mathrm{O}$-antigen treated groups of fish.

In the first hours after injection the proportion of monocytes was reduced (Fig. 3b). The greatest proportion of monocytes was found at $48 \mathrm{~h}$ post-injection in both bacterin-treated fish groups, the values being significantly higher than those observed for the controls. The monocyte numbers had returned to normal $72 \mathrm{~h}$ after injection.

The proportion of lymphocytes tended to decrease in the bacterin- and saline-injected fish, the decrease being most dramatic in the $24 \mathrm{~h}$ sample taken from fish injected with Pasteurella piscicida O-antigen bacterin. By 72 h after injection (Fig. 3c), the lymphocyte values in all 3 groups of fish approximated the normal (zero time) values. Significant differences $(p<0.05$ ) were found in the proportion of lymphocytes between $P$. piscicida $\mathrm{O}$-antigen treated fish and saline-treated fish 24 h post-injection.

Thrombocytes showed a significant increase in the $6 \mathrm{~h}$ sample in all 3 groups of fish. By $12 \mathrm{~h}$ post-injection, the proportion of thrombocytes in all 3 groups of fish began to decrease and by $72 \mathrm{~h}$ after injection, it returned to normal (Fig, 3d). Thrombocyte values in the 3 groups of fish were not significantly different from each other at any time during the experiment.

The effects of i.p. injection of saline and Pasteurella piscicida or Vibrio damsela O-antigen bacterin on the mature cellular population of the head kidney are shown in Fig. 4. The proportion of head kidney neutrophils and macrophages increased significantly relative to that of the controls $48 \mathrm{~h}$ after injection in the 2 $\mathrm{O}$-antigen treated groups of fish $(p<0.01)$. Following this, the proportion of head kidney neutrophils and macrophages decreased in both immunized groups so that after $72 \mathrm{~h}$ (neutrophils) and $168 \mathrm{~h}$ (macrophages), they had returned to normal values. Head kidney lymphocytes dipped briefly but significantly ( $p<0.05$ ) below the control values at $48 \mathrm{~h}$ post-injection. The proportion of head kidney thrombocytes in the $2 \mathrm{O}$ antigen treated and control groups was relatively unchanged during the experiment, the values for the 3 groups not being significantly different from each other at any given sampling time.

Phagocytosis of SRBC by peroxidase-positive and -negative phagocytes of head kidney was observed. 
The proportion of cells with phagocytic ability was higher in the bacterin-treated than in the salineinjected control turbot (Fig 5). In the Vibrio damsela $\mathrm{O}$-antigen treated turbot the phagocytic activity of the pronephric leucocytes against SRBC increased sharply
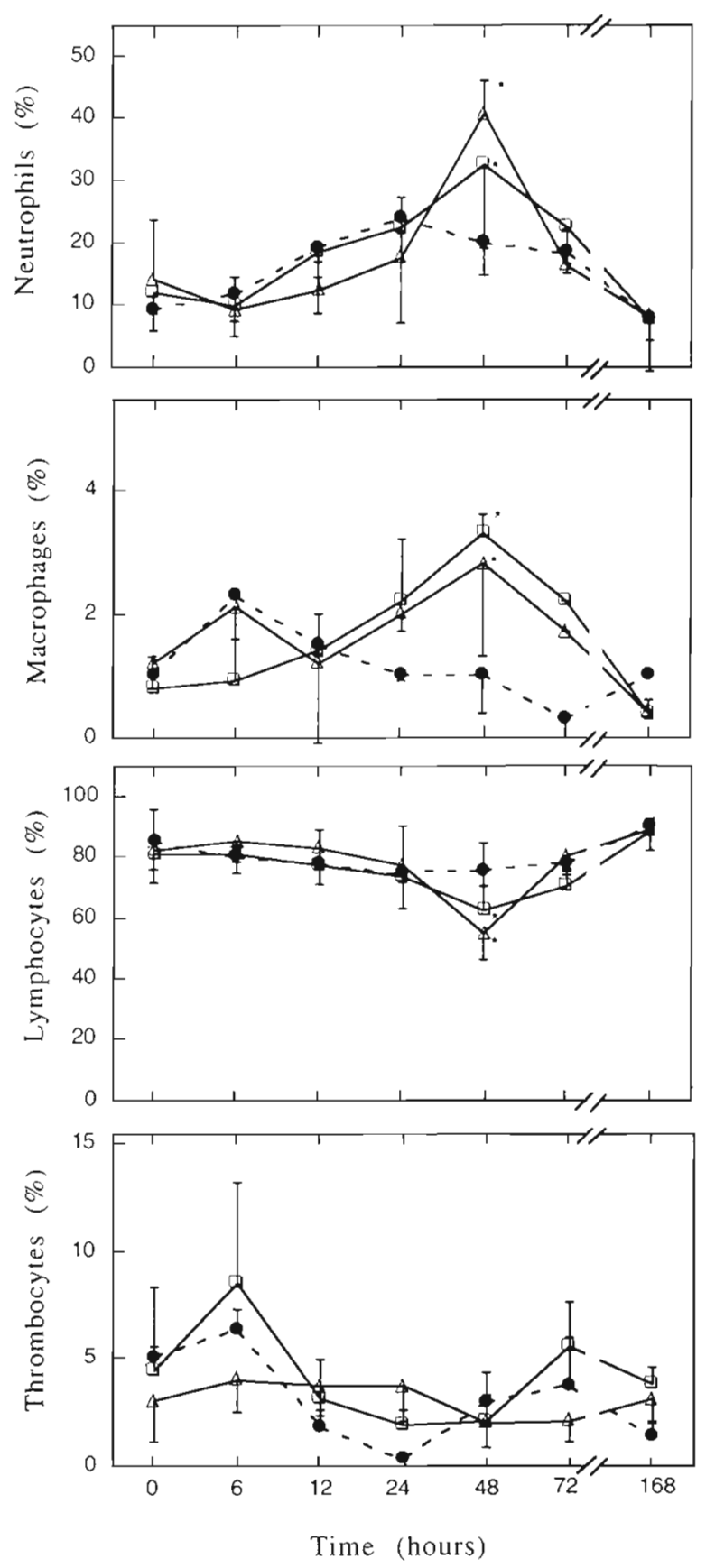

Fig. 4. Scophthalmus maximus. Differential cell counts of head kidney leucocytes at various times after injection of turbot with Vibrio damsela O-antigen ( $\square$ ), Pasteurella piscicida $\mathrm{O}$-antigen $(\Delta)$, or PBS $(-$ ). Each data point represents the mean \pm SD from 5 fish. * Significant differences $(p<0.05)$ between groups treated with bacterins and saline-treated group

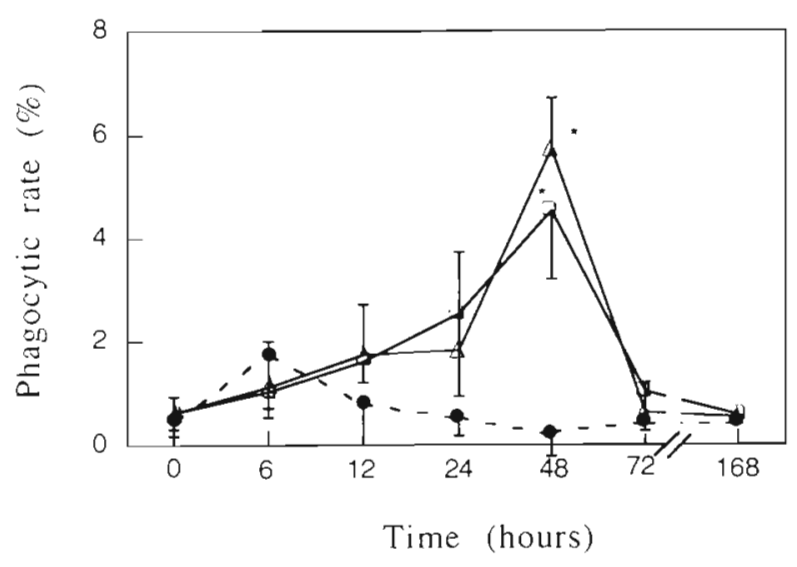

Fig. 5 Scophthalmus maximus. Kinetics of phagocytic rates of head kidney leucocytes from turbot injected with Vibrio damsela O-antigen ( $\square)$, Pasteurella piscicida O-antigen $(\Delta)$. or PBS ( Each data point represents the mean \pm SD from 5 fish. * Significant differences $(p<0.05)$ between groups treated with bacterins and saline-treated group

within $24 \mathrm{~h}$, reaching its maximum within $48 \mathrm{~h}(4.5 \%$ phagocytic rate), and decreased to control levels thereafter. Similar activity was found in fish immunized with Pasteurella piscicida O-antigen with a maximum response at $48 \mathrm{~h}$ after injection ( $5.7 \%$ phagocytic rate). Significant differences were found $48 \mathrm{~h}$ post-injection between the bacterin-treated groups and the salineinjected controls $(p<0.01)$.

Injection of turbot with Vibrio damsela or Pasteurella piscicida $O$-antigen tended to increase the concentration of plasma proteins present relative to that found in the saline-injected control turbot (Fig. 6). However, it was only at $48 \mathrm{~h}$ after injection that this effect was significant $(p<0.05)$.

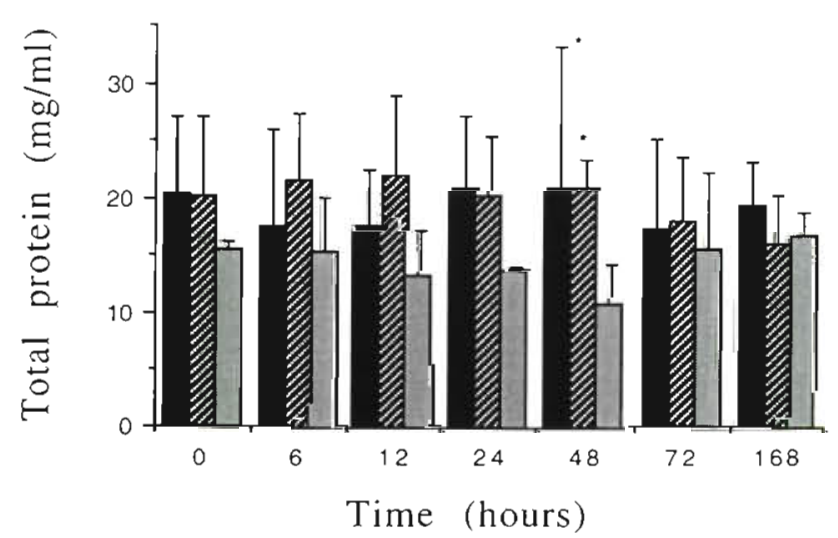

Fig. 6. Scophthalmus maximus. Total plasma protein concentration in turbot injected with Vibrio damsela O-antigen (ם),

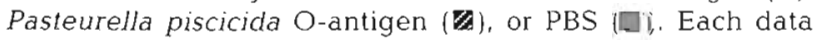
point represents the mean \pm SD from 5 fish. * Significant differences $(p<0.05)$ between groups treated with bacterins and saline-treated group 
Table 1 Scophthalmus maximus. Rate of phagocytosis of sheep red blood cells by the peripheral blood, head kidney, and spleen phagocytes from turbot injected with Vibrio damsela $\mathrm{O}$-antigen and phosphate buffered saline (PBS). Data are expressed as mean $\pm S D ; n=5$ in all groups. Peripheral blood, head kidney, and spleen leucocytes were obtained from fish $48 \mathrm{~h}$ after injection with $\mathrm{O}$-antigen or PBS

\begin{tabular}{|lccc|}
\hline \multicolumn{4}{c}{ Phagocytic rate (\%) } \\
\hline & Peripheral blood & Head kidney & Spleen \\
\hline O-antigen & $4.7 \pm 1.0^{\circ}$ & $4.1 \pm 1.2^{*}$ & $2.9 \pm 1.3$ \\
PBS & $0.7 \pm 0.5$ & $1.6 \pm 0.7$ & $2.0 \pm 0.7$ \\
& & & \\
- Statistically different from saline controls $(\mathrm{p}<0.05)$
\end{tabular}

The phagocytic rates of the head kidney and peripheral blood phagocytes were significantly higher ( $p<$ 0.05 ) in the Vibrio damsela O-antigen injected turbot than rates for phagocytes from saline-injected control turbot (Table 1). However, the phagocytic activity of peripheral blood phagocytes from $\mathrm{O}$-antigen injected turbot was not found to be significantly greater than that found for kidney and spleen phagocytes from $\mathrm{O}$ antigen injected turbot.

\section{DISCUSSION}

In the present study, significant changes in haematological and phagocytosis parameters were observed in turbot after intraperitoneal injection with Vibrio damsela and Pasteurella piscicida bacterins. The baseline haematocrit values (17 to $22 \%$ ) were slightly higher than those reported by Quentel \& Obach (1992), but no significant differences in the haematocrit values were found for the $\mathrm{O}$-antigen treated and control turbot.

The differential leucocyte counts revealed that lymphocytes constituted the major leucocyte population in the peripheral blood and head kidney. Some authors have reported a lower proportion of lymphocytes and a higher proportion of thrombocytes in turbot peripheral blood than we found in the present study (Quentel \& Obach 1992, Burrows \& Fletcher 1987). These discrepancies may be due to difficulties in distinguishing between the 2 cell types when thrombocytes are in the round form. Thrombocytes are supposed to play a role in fish blood coagulation similar to that of the platelets in mammalian blood (Fange 1994), and the significant increase in the number of peripheral blood thrombocytes in both immunised and saline-injected turbot $6 \mathrm{~h}$ after injection may have been due to the lesion effect produced by the injection.

Several authors have described changes in the number of macrophages and neutrophils in the inflammatory process of fish (MacArthur et al. 1984, Suzuki \&
Hibiya 1986, Park \& Wakabayashi 1989). These authors showed that during the inflammation, the neutrophils stored in the head kidney are released into the blood circulation before migration to the area of the inflammation. In the present study, the number of neutrophils increased markedly in peripheral blood within $24 \mathrm{~h}$ after immunization while kidney neutrophils attained their maximum levels $48 \mathrm{~h}$ after injection. Both populations of cells returned to normal levels at about Day 7 post-injection. Increments in neutrophils numbers have been described in catfish as a result of increased stress (Bly et al. 1990). These authors observed an increase of neutrophils in peripheral blood and kidney 24 and $72 \mathrm{~h}$ post-stress, respectively. In the present study we also found a slight increase in the number of neutrophils in the controls, but the changes found in the numbers of neutrophils or monocytes/macrophages detected in the $\mathrm{O}$-antigen bacterin-treated fish were significantly different to those for the controls. Considering the high levels of significance $(p<0.01)$, this could only be explained by the bacterin injection.

The kinetic curves of the phagocytic activity peaked at $48 \mathrm{~h}$ after bacterin injection, a stage coinciding with the highest levels of neutrophils and monocytes in the kidney. Because the injection of the bacterins resulted in a significant increase in the phagocytic activity of blood and head kidney phagocytes towards a heterologous antigen (SRBC), it appears that the bacterins did, in fact, stimulate a non-specific immune response. This result confirms the findings of others (Anderson \& Jeney 1991, Anderson et al. 1991).

Interestingly, we found that neutrophils of turbot are positive for benzidine peroxidase, contrary to what was stated by Ainsworth (1992) in his review. Phagocytosis of SRBC by turbot leucocytes was observed in both peroxidase-positive and -negative staining cells. Cannon et al. (1980) suggested that peroxidase-positive granules strongly indicate phagocytic functions

In our results, the proportion of phagocytic cells that ingested SRBC did not correspond to the increase in the numbers of kidney neutrophils and macrophages. In addition, the proportion of actively phagocytic cells was far lower than that reported in other studies (Anderson \& Jeney 1991). This low phagocytic capability may have been due to our culture conditions and/or to the nature of the foreign material used in this experiment. In fact, phagocytosis by channel catfish Ictalurus punctatus leucocytes of polystyrene beads has not been observed (Ellsaesser et al. 1985) while phagocytosis of bacteria by the leucocytes of the same fish species has been reported (Finco-Kent \& Thune 1987). Furthermore, Griffin (1982) reported that phagocytic cells interact with non-self particles through a variety of mechanisms that depend both on the recognition 
units on the cell surface and on the nature of the interacting particle. It is well established that coating particles with serum opsonins enhances their ingestion by phagocytes due to the $F c$ and $C$ receptors on the surface of phagocytes (Griffin 1983, Sakai 1984, Ainsworth \& Dexiang 1990, Yoshida \& Kitao 1991). However, other authors have stated that the opsonic effects of antibody and complement were lacking in plaice Pleuronectes platessa and dogfish Scyliorhinus canicula (Wrathmell \& Parish 1980). Further work will be necessary to elucidate the opsonic effect of antiserum and complement on phagocytosis of SRBC by turbot leucocytes

The higher total protein levels found in serum of bacterin-injected turbot may due to an increase in the production of non-specific defence factors. Elevations of levels of C-reactive protein, ceruplasmin, and lysozyme after immunization have been reported in carp and rainbow trout (Siwickı \& Studnicka 1986, Murai et al. 1990, Rainger \& Rowley 1993).

In contrast to the study with the eel Anguilla japonica (Park \& Wakabayashi 1992), the present work showed no difference in phagocytic capacity between head kidney phagocytes and the blood peripheral phagocytes.

Acknowledgement5. M.M.S. thanks the Junta Nacional de Investigaçâo Científica e Tecnológica (Portugal) for a research fellowship. We thank Drs Alicia Toranzo and Belén Fouz from the Microbiology Department, Santiago de Compostela, Spain, for providing the virulent strains of Vibrio damsela and Pasteurella piscicida used in this study. This work was supported by CICYT grant number MAR91-1133CO2-O2 and AGF94-1360-CO3-O3 from Spain.

\section{LITERATURE CITED}

Ainsworth AJ (1992) Fish granulocytes: morphology, distribution, and function. In: Faisal M, Hetrick FM (eds) Annual review of fish diseases, Vol 2. Pergamon Press, New York, p $123-148$

Ainsworth AJ, Dexiang C (1990) Differences in the phagocytosis of four bacteria by channel catfish neutrophils. Dev comp Immunol 14:201-209

Anderson DP, Jeney G (1991) Responses to in vitro and in vivo immunizations with Aeromonas salmonicida $O$ antigen bacterins in rainbow trout (Oncorhynchus mykiss). Fish Shellfish Immunol 1:251-260

Anderson DP, Moritamo T, De Grooth R (1991) Neutrophil, glass-adherent, nitroblue tetrazolium assay gives early indication of immunization effectiveness in rainbow trout. Vet Immunol Immunopathol 30:419-429

Baudin Laurencin F, Batellier F (1986) Protection immunitaire du turbot (Scophthalmus maximus) contre la vibriose. In: Vivares CP, Bonami JR, Jaspers E (eds) Pathology in marine aquaculture. Spec Publ 9, European Aquaculture Society, Bredene, Belgium, p 391-403

Bly JE, Miller NW, Clem LW (1990) A monoclonal antibody specific for neutrophils in normal and stressed channel catfish. Dev comp Immunol 14:211-304
Burrows AS, Fletcher TC (1987) Blood leukocytes of the turbot Scophthalmus maximus L. Aquaculture 67:214-215

Cannon MS, Mollenhauer HH, Cannon AM, Eurell TE, Lewis DH (1980) Ultrastructural localization of peroxidase activity in neutrophil leukocytes of Ictalurus punctatus. Can J Zool 58:1139-1143

Dec C, Angelidis P, Baudin Laurencin F (1990) Effects of oral vaccination against vibriosis in turbot, Scophthalmus maximus (L.), and sea bass, Dicentrarchus labrax (L.). J Fish Dis 13:369-376

Edwards PR, Ewing WH (eds) (1972) Identification of Enterobacteriaceae. Burgess Publishing Company, Minneapolis

Ellis AE, Munroe ALS, Roberts RJ (1976) Defense mechanisms in fish. 1. A study of the phagocytic system and the fate of intraperitoneally injected particulate material in the plaice (Pleuronectes platessa L.). J Fish Biol 8:67-78

Ellsaesser C, Miller NW, Cuchens MA, Lobb CJ, Clem LW (1985) Analysis of channel catfish peripheral blood leukocytes by bright-field microscopy and flow cytometry Trans Am Fish Soc 114:279-285

Fange R (1994) Blood cells, haemapoiesis and lymphomyeloid tissues in fish. Fish Shellfish Immunol 4:405-411

Finco-Kent D. Thune RL (1987) Phagocytosis by catfish neutrophils. J Fish Biol 31(Suppl A):41-49

Fouz B, Larsen JL, Toranzo AE (1991) Vibrio damsela as a pathogenic agent causing mortalities in cultured turbot (Scophthalmus maximus). Bull Eur Ass Fish Pathol 11 : $80-81$

Fukuda Y, Kusuda R (1981) Efficacy of vaccination for pseudotuberculosis in cultured yellowtail by various routes of administration. Bull Jap Soc scient Fish 47 141-150 (in Japanese with English abstract)

Fukuda Y. Kusuda R (1985) Vaccination of yellowtail against pseudotuberculosis. Fish Pathol 20:421-425

Griffin BR (1983) Opsonic effect of rainbow trout (Salmo gaurdneril antibody on phagocytosis of Yersinia ruckeri by trout leukocytes. Dev comp Immunol 7:253-259

Griffin FM Jr (1982) Mononuclear cell phagocytic mechanisms and host defense. In: Gallin JI, Fauci AS (eds) Advances in host defense mechanisms. Raven Press, New York, p 31-55

Kimura M, Kitao T (1971) On the etiological agent of 'bacterial tuberculoidosis' of Seriola. Fish Pathol 6:8-14

Kusuda R, Hamaguchi M (1988) The efficacy of attenuated live bacterin of Pasteurella piscicida against pseudotuberculosis in yellowtail. Bull Eur Ass Fish Pathol 8:51-53

Kusuda R, Yamaoka M (1972) Etiological studies on bacterial pseudotuberculosis in cultured yellowtail with Pasteurella piscicida as the causative agent -- I. On the morphological and biochemical properties. Nippon Suisan Gakk 38: $1325-1332$

Jeney G, Anderson DP (1993) Enhanced immune response and protection in rainbow trout to Aeromonas salmonicida bacterin following prior immersion in immunostimulants. Fish Shellfish Immunol 3:51-58

MacArthur JI, Fletcher TC, Pirie BJS, Davidison RJL, Thompson AW (1984) Peritoneal inflammatory cells in plaice, Pleuronectes platessa L : effects of stress and endotoxin. J Fish Biol 25:69-81

Murai H, Kodama H, Naiki M, Mikami M, Izama H (1990) Isolation and characterisation of rainbow trout C-reactive protein. Dev comp Immunol 14:49-58

Park SW, Wakabayashi H (1989) Kinetics of neutrophils in the kidney of eel, Anguilla japonica, intraperitoneally injected with formalin-killed Escherichia coli as an irritant. Fish Pathol 24:233-239 (in Japanese with English abstract)

Park SW, Wakabayashi H (1992) Comparison of pronephric 
and peripheral blood neutrophils of eel, Anguilla japonica, in phagocytic actıvity. Gyobyo Kenkyu 27 (3):149-152

Quaglino D, Flemans R (1958) Peroxidase staining in leukocytes. Lancet 11:1020

Quentel C, Obach A (1992) The cellular composition of the blood and haematopoietic organs of turbot Scophthalmus maximus L. J Fish Biol 41:709-716

Rainger GE, Rowley A F (1993) Antibacterial activity in the serum and mucus of rainbow trout, Onchorhynchus mykiss, following immunisation with Aeromonas salmonicida. Fish Shellfish Immunol 3:475-482

Rijkers GT (1982) Non-lymphoid defense mechanism in fish. Dev comp Immunol 6:1-13

Sakai DK (1984) Opsonization by fish antibody and complement in the immune phagocytosis by peritoneal exudate cells isolated from salmonid fishes. J Fish Dis 7:29--38

Santarem MM, Figueras A (1994) Kinetics of phagocytic activity, plaque-forming cells and specific agglutinins of turbot (Scophthalmus maximus L.) immunized with $\mathrm{O}$ antigen of Vibrio damsela and Pasteurella piscicida. Fish Shellfish Immunol 4:527-537

Siwicki A, Studnicka M (1986) Ceruplasmin activity in carp (Cyprinus carpio L.). Bamidgeh 38:126-129

Suzuki Y, Hibiya T (1986) Dynamics of leucocytic inflammatory responses in carp. Fish Pathol 23:179-184

Toranzo AE, Barja JL (1990) A review of the taxonomy and seroepizootiology of Vibrio anguillarum with special refer-

Responsible Subject Editor: T Evelyn, Nanaimo, British Columbia, Canada ence to aquaculture in the northwest of Spain. Dis aquat Org 9:73-82

Toranzo AE, Barreiro S, Casal JF, Figueras A, Magariños B, Barja JL (1991) Pasteurellosis in cultures of gllthead seabream (Sparus aurata); first report in Spain. Aquaculture 99:43-44

Toranzo AE, Novoa B, Romalde JL, Nuñez S, Devesa S, Marino E. Silva R. Martínez E, Figueras A, Barja JL (1993) Microflora associated with healthy and diseased turbot (Scophthalmus maximus) from three farms in northwest Spain. Aquaculture 114:189-202

Toranzo AE, Santos Y, Bandín I, Romalde JL, Ledo A. Barja JL (1990) Five year survey of bacterial fish infections in continental and marine aquaculture in northwest of Spain. World Aquacult 21:91-94

Toranzo AE, Santos Y, Lemos ML, Ledo A, Bolinches J (1987) Homology of Vibrio anguillarum strains causing epizootics on turbot, salmon and trout reared in the Atlantic coast of Spain. Aquaculture 67:41-52

Wrathmell AB, Parish NM (1980) Cell surface receptors in the immune response in fish. In: Manning MJ (ed) Phylogeny of immunological memory. Elsevier/North Holland Biochemical Press, Amsterdam, p 143-152

Yoshida T, Kitao T (1991) The opsonic effect of specific immune serum on the phagocytic and chemiluminescent response in rainbow trout, Oncorhynchus mykiss phagocytes. Gyobyo Kenkyu 26(1):29-33

Manuscript first received: July 4, 1994

Revised version accepted: June 7, 1995 